DOI 10.31558/2518-7953.2019.1.13

УДК 347.91

\begin{abstract}
I. В. Атаманчук доцент кафедри цивільного права і процесу Донецького національного університету імені Василя Стуса, канд. юрид. наук
\end{abstract}

\title{
ВПРОВАДЖЕННЯ ЄВРОПЕЙСЬКИХ СТАНДАРТІВ У СФЕРУ ПРОЦЕСУАЛЬНО-ПРАВОВОГО РЕГУЛЮВАННЯ ЦИВІЛЬНОГО СУДОЧИНСТВА УКРАЇНИ
}

Ключові слова: прочесуально-правове регулювання, иивільне судочинство, європейські стандарти, принципи судочинства, міжнародне правове співробітництво, гармонізація процесуального законодавства.

Реформування судової системи є складним процесом, що потребує вирішення широкого кола проблем, пов'язаних з приведенням вітчизняного цивільного процесуального законодавства у відповідність до стандартів законодавства Європейського Союзу. Правові орієнтири судового співробітництва у цивільних справах на законодавчому рівні були задекларовані у ратифікованій в 2014 році Угоді про асоціацію між Україною, з однієї сторони та Європейським Союзом, Європейським співтовариством з атомної енергії і їхніми державами-членами, з іншої сторони. До визначених напрямів подальшого розвитку цивільного судочинства віднесено принципи юридичної визначеності і право на справедливий суд, досягнуто домовленості про судове співробітництво у цивільних справах на основі відповідних багатосторонніх правових документів, зокрема конвенцій Гаазької конференції з міжнародного приватного права у сферах міжнародного правового співробітництва, судового процесу (п. 1-2 ст. 24) [1]. Досягнені домовленості створили правове підгрунтя для комплексного реформування процесуального законодавства 3 метою приведення його у відповідність до міжнародних стандартів. На цьому підгрунті було внесено численні зміни до Цивільного процесуального кодексу України: удосконалено регулювання класичних процедур цивільного судочинства, введено нові правові інститути. При цьому, впровадження європейських стандартів у сферу цивільного судочинства є складним процесом, який потребує 
визначення послідовності дій, етапів, процедур, правових механізмів, урахування особливостей національного законодавства та динаміки змін у правовій системі Свропейського Союзу, що ускладнює формування ефективної правової бази.

У правовій науці такі принципи судочинства, як принцип юридичної визначеності, право на справедливий суд та ін. часто розглядаються як певні міжнародні стандарти цивільного судочинства, які необхідно впроваджувати у вітчизняне процесуальне законодавство, але при цьому науковці залишають поза увагою різне змістовне наповнення юридичних категорій «принципи» та «стандарти». За відсутності нормативних визначень термінів «принципи судочинства» та «стандарти судочинства» постає потреба у їх юридичному тлумаченні для подальшого визначення обсягів правового регулювання та випрацювання уніфікованої системи юридичних понять. Таке впорядкування термінології надасть можливість вироблення ефективних правових інструментів конвергенції правової системи судочинства України з європейською правовою системою.

Загальнотеоретичні питання впровадження європейських стандартів, зокрема, у сферу процесуально-правового регулювання цивільного судочинства, реформування судової системи України в контексті європейської інтеграції досліджувались у працях С. В. Васильєва, В. А. Василенко, Н. Ю. Голубєвої, В. Н. Денисова, А. С. Довгерта, В. К. Забігайла, І. В. Назарова, Ю. Д. Притики, В. І. Тертишнікова, В. Ф. Усенка, Ю. С. Шемшученка, М. Й. Штефана, І. В. Яковюка та ін.

Вузьконаправлені дослідження цієї тематики здійснювались багатьма авторами. Зокрема, В. В. Бонтлаб провів аналіз сучасного стану поняття та ознак міжнародних стандартів цивільного судочинства, запропонував їх визначення, виділив ознаки [2]. І. М. Яворська розглянула роль і значення рішень Суду Свропейського Союзу у процесі гармонізації законодавства України з правом СС та зробила висновок про необхідність застосування прецедентної практики Суду Свропейського Союзу під час нормопроектування [3]. В. А. Кройтор та Т. В. Степаненко дослідили стандарти Європейського Союзу у сфері цивільного судочинства і проблему доступу до правосуддя [4]. Р. Ф. Гонгало проаналізувала аспекти імплементації практики Європейського суду з прав людини в цивільне процесуальне право України [5, с. 163-172]. В. Г. Перепелюк розглянув фактори, які впливають на процеси уніфікації процесуального права, зокрема, проаналізував суперечності між такими факторами, як практика Свропейського суду з прав людини та практика Конституційного Суду України [6]. Т. А. Стоянова розглянула практику Свропейського суду з прав людини як джерело цивільного процесуального права України [5, с. 172-180]. Певні дослідження поняття «стандарти цивільного процесу» здійснила I. О. Ізарова, в основу яких вона поклала аналіз напрацювань Дослідницького центру Європейського Парламенту під назвою «Спільні мінімальні стандарти цивільного процесу», визначення з Резолюції Свропейського Парламенту 
від 4 липня 2017 р. та зробила висновки про необхідність запозичення Україною передового досвіду, не втрачаючи при цьому переваг національного підходу до вирішення цивільних справ [7, с. 58-61]. Однак, на сьогодні щодо правового забезпечення впровадження європейських стандартів у сферу процесуально-правового регулювання цивільного судочинства в Україні залишається ще багато недосліджених питань. Зокрема, відсутнє чітке уявлення стосовно того, що являють собою стандарти, які підлягають впровадженню у сферу процесуально-правового регулювання здійснення цивільного судочинства в Україні.

Наведене вище вказує на актуальність теми цієї статті.

Метою цієї статті є обтрунтування пропозииій щуодо впровадження європейських стандартів у сферу процесуально-правового регулювання здійснення ичиільного судочинства в Україні.

Правова система Європейського Союзу функціонує на засадах єдності, тому перед українською державою стоїть завдання імплементувати міжнародні стандарти цивільного судочинства у вітчизняну систему цивільного процесуального законодавства, що дасть можливість забезпечити оптимальні умови правового регулювання національного судочинства, де норми процесуального права несуть основне навантаження нормативного способу забезпечення законності, гарантування захисту прав, свобод і законних інтересів громадян, оскільки забезпечують реалізацію відповідних матеріальних норм.

Відповідно до статті 51 Угоди про партнерство та співробітництво між Україною і Свропейським Співтовариством від 16 червня 1994 року Україна взяла на себе зобов'язання вживати заходів для поступового приведення національного законодавства у відповідність із законодавством Європейського Союзу у різних сферах [1]. Законодавчі засади такої адаптації були визначені у Загальнодержавній програмі адаптації законодавства України до законодавства Європейського Союзу (далі - Програма), затвердженій Законом України від 18 березня 2004 року. Ця Програма має за мету визначення механізмів досягнення Україною відповідності третьому Копенгагенському та Мадридському критеріям набуття членства в Європейському Союзі [8], що дасть можливість проведення адаптації законодавства України до законодавства Свропейського Союзу.

Процес адаптації передбачає вжиття необхідних заходів для ефективного правотворення процесуальних норм та правозастосування у ході здійснення цивільного судочинства, забезпечення реалізації права на судовий захист. Згідно 3 Програмою метою адаптації законодавства України до законодавства Європейського Союзу є досягнення відповідності правової системи України acquis communautaire з урахуванням критеріїв, що висуваються Європейським Союзом до держав, які мають намір вступити до нього, тобто acquis communautaire виступає у якості своєрідного стандарту, зразка. 
Термін acquis communautaire (acquis) визначається у Програмі як правова система Європейського Союзу, що включає акти законодавства Європейського Союзу (але не обмежується ними), прийняті в рамках Європейського співтовариства, спільної зовнішньої політики та політики безпеки і співпраці у сфері юстиції та внутрішніх справ [8]. Виходячи з цього визначення, стандарт acquis communautaire являється дуже об'ємним та широким за своїм змістовним наповненням, саме тому серед науковців немає єдиного загального підходу щодо визначення його обсягу і змісту, як і немає загального підходу щодо розмежування понять «міжнародні принципи судочинства» та «міжнародні стандарти судочинства», які часто вживаються як синоніми. Наприклад, С. М. Ляхівненко вважає, що до міжнародних стандартів відносяться норми та принципи, що приймаються в порядку, закріпленому чинним законодавством [9, с. 671], а В. Барбара пропонує розглядати міжнародні стандарти у сфері судочинства як авторитетні узгоджені узагальнення (висновки) належної практики та провідних принципів, що їх має досягти кожна держава на національному рівні [10, с. 312].

Звертаючись до Бангалорських принципів поведінки суддів, схвалених Резолюцією Економічної та Соціальної Ради ООН 27.07.2006 p. № 2006/23, можна спостерегти, що на рівні міжнародного законодавства пропонується розглядати принципи як підгрунтя, основу, інструкцію для встановлення стандартів [11]. Така ситуація, зазначає Р. А. Петров, дає можливість інститутам Європейського Союзу вводити в правовий обіг нові підвиди поняття «асquis communautaire», i, як наслідок, позначати їх обсяг і зміст на свій розсуд, відповідно до цілей зовнішньої політики Свропейського Союзу [12, с. 2]. Аналізуючи подібний підхід, Я. Романюк висловлює погляд, що визнані прогресивною міжнародною спільнотою стандарти у сфері судочинства - принципи, рекомендації, правила, критерії - містяться в різноманітних за своєю правовою природою документах, мають різний рівень - загальносвітовий чи європейський. Вони можуть носити для України як обов'язковий, так і необов'язковий характер [10, с. 10].

Як вбачається 3 наведеного, змістовне наповнення поняття acquis communautaire $\epsilon$ предметом численних наукових дискусій. При цьому, зокрема, Р. А. Петров на підставі аналізу обсягу і змісту поняття «асquis communautaire» у сучасній науці права Європейського Союзу робить висновок про те, що поняття «асquis communautaire» часто вживається як синонім до поняття «законодавство $€ C$ », а серед присутніх у «асquis communautaire» елементів він визначає практику судових органів Свропейського Союзу - «Судовий асquis» як частину «фундаментального acquis», впровадження якого є необхідною умовою членства в Європейському Союзі [12, с. 2, 3,8].

«Судовий асquis» передбачає приведення цивільного процесуального законодавства України у відповідність із рішеннями Суду Європейського Союзу. Одним 
iз кроків у напрямі створення правових механізмів виконання рішень Свропейського суду було прийняття у 2006 році Закону України «Про виконання рішень та застосування практики Європейського суду з прав людини», у преамбулі якого вказується на обов'язок держави щодо впровадження європейських стандартів прав людини в українське судочинство [13]. Відсутність систематизованого нормативного регулювання послідовності процедур впровадження європейських правових стандартів тягне за собою невизначеність поняття та переліку стандартів цивільного судочинства, які підлягають впровадженню, тому цілком слушною $\epsilon$ пропозиція I. В. Яковюк, висловлена у ході дослідження проблеми адаптації законодавства України до законодавства Європейського Союзу. І. В. Яковюк відзначає, що для успішного проведення адаптації важливе значення має впорядкування юридичної термінології, а вироблення сталої системи юридичних понять і термінів $\epsilon$ необхідною умовою, одним із пріоритетних напрямів правового реформування [14, с. 38].

Досліджуючи питання правового забезпечення впровадження європейських стандартів у сферу процесуально-правового регулювання здійснення судочинства у цивільних справах, неможливо обійти увагою поняття спільних мінімальних стандартів цивільного процесу, розглянутих I. О. Ізаровою, на основі ухваленої у 2017 р. Резолюції Європейського Парламенту, що включає рекомендації Комісії щодо спільних мінімальних стандартів цивільного процесу в Європейському Союзі (2015/2084(INL)). До них віднесено, зокрема, визначення заходів ефективного судового захисту, вимог до проведення усних слухань (судових засідань), застосування забезпечувальних заходів, мотивованості рішень, загальних принципів щодо управління провадженням (організації розгляду справи), порядку надання доказів, залучення судових експертів, особливостей врегулювання спору без судового розгляду, забезпечення права на адвоката в цивільному судочинстві, доступу до інформації, вимоги до публічного судового розгляду, забезпечення незалежності та неупередженості судів та ін. [7, с. 55, 56].

У рамках науково-теоретичного підходу (Н. Ю. Сакара, В. А. Кройтор) до джерел визначення понять та видів стандартів цивільного судочинства прийнято відносити міжнародні норми, рішення та практику Європейського суду з прав людини. Так, Конвенція про захист прав людини і основоположних свобод від 04.11.1950 р., ратифікована Законом України від 17.07.1997 р. у своїй преамбулі проголошує верховенство права, що пов'язується з функціонуванням незалежних та неупереджених органів судочинства. Стаття 6 Конвенції вказує, що кожен має право на справедливий і публічний розгляд його справи упродовж розумного строку незалежним і безстороннім судом, встановленим законом, який вирішить спір щодо його прав та обов'язків цивільного характеру [15]. Виходячи з наведених положень Конвенції можна зробити висновок, що до європейських стандар- 
тів цивільного судочинства належать доступність та неупередженість судочинства, законність, право на справедливий суд, забезпечення виконання судових рішень, удосконалення системи правосуддя. Подібний підхід до визначення переліку стандартів цивільного судочинства, що підлягають впровадженню в систему українського судочинства, отримав сучасну наукову підтримку [10, с. 3-6], деякі дослідники поділяють стандарти на групи, беручи за основу певний критерій, найчастіше, спосіб або форму їх закріплення (О. Старцев, В. Д. Бринцев, О. Саленко). Так, В. В. Бонтлаб пропонує класифікувати стандарти цивільного судочинства на міжнародні універсальні, міжнародні регіональні та національні, та робить висновок про необхідність врахування до вимог стандартів міжнародних та національних (конституційних) принципів цивільного судочинства [2, с. 5, 6].

Виходячи з викладеного, можна вказати такі ключові європейські стандарти, що підлягають впровадженню у сферу процесуально-правового регулювання цивільного судочинства в Україні: доступність правосуддя у цивільних справах; незалежний та справедливий суд; ефективний судовий захист та виконання судових рішень. Ці стандарти названі в схваленій у 2015 році Указом Президента України Стратегії реформування судоустрою, судочинства та суміжних правових інститутів на 2015-2020 роки, яка набрала чинності 26 травня 2015 року. Серед пріоритетів реформування системи судоустрою, судочинства та суміжних правових інститутів у Стратегії було визначено необхідність практичної реалізації принципу верховенства права та забезпечення функціонування судової влади, що відповідає суспільним очікуванням щодо незалежного та справедливого суду, а також європейським цінностям та стандартам захисту прав людини (р. 2) [16].

Досліджуючи процес імплементації міжнародних правових норм у сферу цивільного судочинства, слід зважати на динамічний характер цивільних процесуальних норм та особливість форми їх закріплення. Основним нормативним актом, який регулює здійснення цивільного судочинства є Цивільний процесуальний кодекс України, до якого у 2017 році було внесено істотні зміни згідно із Законом України «Про внесення змін до Господарського процесуального кодексу України, Кодексу адміністративного судочинства України та інших законодавчих актів», що були покликані наблизити процес цивільного судочинства у відповідність до європейського стандарту права на справедливий суд та зробити процес судочинства максимально доступним, швидким, ефективним та прозорим.

У нормах Цивільного процесуального кодексу України, крім основних засад (принципів) цивільного судочинства (ч. 3 ст. 2), отримали закріплення: принципи безперешкодного звернення особи до суду (ст. 4); право особи на інформацію щодо справи (ст. 8); верховенство права (ст. 10), з вказівкою у ч. 8 ст. 10, що у разі невідповідності правового акта міжнародному договору, згода на обов'язковість якого надана Верховною Радою України, суд застосовує міжнародний до- 
говір України; запровадження спрощених судових процедур (ч. 4 ст. 19); розумні строки судового розгляду цивільних справ (ст. 121). Отримали розширення інститути юрисдикції, підсудності, доказування, позову, судових рішень та ін. [17]. На сьогодні судова реформа не завершена, а знаходиться у процесі реалізації, тому лишається сподіватися, що реорганізація основних процесуально-правових інститутів здійснення цивільного судочинства в Україні призведе до створення сучасної європейської системи правосуддя.

Підсумовуючи вищевикладене, можна визначити такі ключові європейські стандарти, які підлягають впровадженню у сферу проиесуально-правового регулювання цивільного судочинства в Украӥні: доступність правосуддя у циивільних справах; незалежний та справедливий суд; ефективний судовий захист та виконання судових рішень. Принципи ичивільного судочинства пропонується розглядати як основу для встановлення стандартів. У нормотворчому прочесі впровадження європейських стандартів у сферу проиесуально-правового регулювання ичивільного судочинства Украӥни слід враховувати особливості системних зв'язків національного процесуального законодавства, динаміку змін у європейських моделях ичивільного процесуального регулювання здійснення судочинства.

Слід відзначити, що успішна реалізація комплексу реформ системи судочинства, спрямованих на забезпечення інтеграції України до Європейського Союзу, потребує наукового супроводження не лише щодо проблематики визначення європейських стандартів, які підлягають впровадженню у сферу процесуально-правового регулювання здійснення цивільного судочинства в Україні, але й наукового аналізу інтерпретаційно-правової та правозастосовної діяльності процедур впровадження цих стандартів, що створює перспективні напрями для подальших наукових досліджень.

1. Угода про партнерство та співробітництво між Україною і Європейським Співтовариством та їх державами-членами від 14 червня 1994 р. Офіційний веб-портал Верховної Ради України. URL: http://zakon4.rada.gov.ua/laws/show/998_012

2. Бонтлаб В. В. Поняття та ознаки міжнародних стандартів цивільного судочинства в умовах сьогодення. Часопис Національного університету «Острозька академія». Серія «Право». 2015. № 1(11). URL: https://lj.oa.edu.ua/articles/2015/n1/15bvvvus.pdf

3. Яворська I. М. Значення практики суду Європейського Союзу у процесі гармонізації законодавства України з правом СС. Науковий вісник Львівського державного університету внутрішніх справ. 2010. № 1. URL: http://www2.lvduvs.edu.ua/documents_pdf/visnyky/nvsy/ 01_2010/yimpys.pdf

4. Кройтор В. А., Степаненко Т. В. Стандарти Європейського Союзу в сфері цивільного судочинства і проблема доступу до правосуддя. Наукові записки Харківського економіко-правового університету. 2005. № 1(2). C. 64-76. URL: http://dspace.hepu.edu.ua:8080/xmlui/ bitstream/handle/1/414/Science_Notes_2005_2_64-76.pdf?sequence=1\&isAllowed=y 
5. Актуальні питання цивільного судочинства у світлі судової реформи в Україні: монографія [С. В. Ківалов, Н. Ю. Голубєва, І. В. Андронов та ін.]; за заг. ред.: Н. Ю. Голубєвої; НУ ОЮА. Одеса: Юридична література, 2017. 212 с.

6. Перепелюк В. Г. Уніфікація процесуального права: погляд через призму адміністративного судочинства (частина 1). Публічне право. 2013. № 1. C. 67-72. URL: http://nbuv.gov.ua/ UJRN/pp_2013_1_9

7. Ізарова I. О. Спільні стандарти цивільного процесу в ЄС: загальна характеристика та перспективи реалізації. Наукові записки НаУКМА. Юридичні науки. 2018. Т. 1. С. 55-61. URL: nrplaw.ukma.edu.ua/article/download/153110/152329

8. Про Загальнодержавну програму адаптації законодавства України до законодавства Європейського Союзу: Закон України від 18 березня 2004 р. № 1629-IV. Відомості Верховної Ради Украӥни. 2004. № 29. Ст. 367. (Із змінами).

9. Ляхівненко С. М. Міжнародні правові стандарти: до визначення поняття та видової характеристики. Держава і право. 2011. Вип. 51. С. 666-672.

10. Європейські та міжнародні стандарти у сфері судочинства / ред. група: Д. Вон, I. Зарецька, С. Сученко, В. Валанчюс, Ю. Землицька (відп. ред.), К. Мадоян. Київ, 2015. 708 с.

11. Бангалорські принципи поведінки суддів від 19 травня 2006 р., схвалено Резолюцією Економічної та Соціальної Ради ООН 27 липня 2006 р. № 2006/23. Офіиійний веб-портал Верховної Ради України. URL: https://zakon.rada.gov.ua/laws/show/995_j67

12. Петров Р. А. «Acquis вступу» як складова феномена права Європейського Союзу. Електронний архів Національного університету «Києво-Могилянська академія». URL: http:// ekmair.ukma.edu.ua/bitstream/handle/123456789/1718/Petrov_Acquis\%20vstupu.pdf?sequence=1

13. Про виконання рішень та застосування практики Європейського суду з прав людини: Закон України від 23 січня 2006 р. № 3477-IV. Відомості Верховної Ради Украӥни. 2006. № 30. Ст. 260. (Із змінами).

14. Яковюк I. В. Адаптація законодавства України до законодавства Європейського Союзу: проблеми реалізації. Державне будівництво та місиеве самоврядування: зб. наук. пр. / Нац. акад. прав. наук України, НДІ держ. буд. та місц. самоврядування. Х.: Право, 2012. Вип. 24. С. 37-49.

15. Конвенція про захист прав людини і основоположних свобод від 4 листопада 1950 р., ратифікована Законом України від 17 липня 1997 р. Офіиійний веб-портал Верховної Ради України. URL: https://zakon.rada.gov.ua/laws/show/995_004

16. Про Стратегію реформування судоустрою, судочинства та суміжних правових інститутів на 2015-2020 роки: Указ Президента України від 20 травня 2015 р. № 276/2015. Офіuіiйний вісник України. 2015. № 41. Ст. 1267.

17. Цивільний процесуальний кодекс України від 18 березня 2004 р. Відомості Верховної Ради України. 2004. № 40-41, 42, Ст. 492. (Із змінами). 